Journal Indonesian Language Education and Literature Vol.1, No. 2, 2016

http://www.syekhnurjati.ac.id/jurnal/index.php/jeill/

\title{
HUBUNGAN ANTARA KEMAMPUAN MENYUSUN PARAGRAF DAN MOTIVASI BERPRESTASI DENGAN KETERAMPILAN MENULIS LAPORAN
} (Survei pada Siswa Kelas XI SMK Negeri 1 Sukoharjo)

\author{
Haryanto \\ SMKN 1 Sukoharjo
}

\begin{abstract}
Abstrak
Penelitian ini bertujuan untuk mengetahui ada tidaknya (a) hubungan antara kemampuan untuk mengembangkan paragraf dan melaporkan keterampilan menulis, (2) hubungan antara motivasi berprestasi dan keterampilan menulis laporan, dan (3) hubungan antara kemampuan dan motivasi berprestasi mengatur paragraf bersama-sama dengan keterampilan menulis laporan. Penelitian ini dilakukan di SMK Negeri 1 Sukoharjo, Januari-Juni 2010. Metode penelitian yang digunakan adalah metode survei dengan teknik korelasi. Populasi adalah siswa kelas XI SMK Negeri 1 Sukoharjo. Sampel 60 orang yang diambil secara simple random sampling. Instrumen untuk mengumpulkan data adalah tes keterampilan menulis laporan. Teknik analisis data yang digunakan adalah teknik statistik regresi dan korelasi (sederhana dan ganda). Hasil penelitian menunjukkan bahwa: (1) ada korelasi positif antara kemampuan untuk mengembangkan paragraf dan penulisan laporan keterampilan $(r=0.79$ Y.1 tingkat nyata $\alpha=0,05$ dengan $\mathrm{N}=60$ di mana $\mathrm{rt}=0,254)$, (2) ada adalah hubungan positif antara motivasi berprestasi dan laporan keterampilan menulis ( $\mathrm{r}=0,68$ pada Y.2 nyata tingkat $\alpha=0,05$ dengan $\mathrm{N}=60$ di mana rata. $=0,254)$, dan (3) ada korelasi positif antara kemampuan untuk mengembangkan paragraf dan motivasi berprestasi, bersama-sama dengan keterampilan untuk menulis laporan ( $\mathrm{R}$ y. $12=0,87$ pada $\alpha=0,05$ signifikan dengan $\mathrm{N}=60$ di mana $\mathrm{rt}=0,254$ ). Dari hasil di atas dapat dinyatakan bahwa secara individu atau bersama-sama mengembangkan kemampuan dan motivasi berprestasi paragraf membuat kontribusi yang signifikan terhadap keterampilan menulis laporan. Hal ini menunjukkan bahwa kedua variabel tersebut dapat menjadi prediktor yang baik untuk keterampilan menulis laporan.
\end{abstract}

This study aimed to determine whether there is (a) the relationship between the ability to develop paragraphs and report writing skills, (2) the relationship between achievement motivation and skills to write reports, and (3) the relationship between ability and achievement motivation arrange paragraphs together with the skills write reports. This research was conducted at SMK Negeri 1 Sukoharjo, January to June 2010. The research method used is survey method with correlation techniques. The population was eleventh grade students of SMK Negeri 1 Sukoharjo. The sample of 60 people taken by simple random sampling. Instruments to collect data is a test of skills to write reports, prepare ability test paragraph, and achievement motivation questionnaire. Data analysis techniques used are statistical techniques of regression and correlation (simple and double). The results showed that: (1) there is a positive correlation between the ability to develop paragraphs and report writing skills $(\mathrm{r}=0.79$ Y.1 the real level $\alpha=0.05$ with $\mathrm{N}=$ 60 where $\mathrm{rt}=0.254)$, (2) there was a positive relationship between achievement motivation and report writing skills ( $\mathrm{r}=0.68$ at Y.2 real level $\alpha=0.05$ with $\mathrm{N}=60$ where Avg. $=0.254$ ), and (3) there was a positive correlation between the ability to develop 


\section{Journal Indonesian Language Education and Literature Vol.1, No. 2, 2016}

http://www.syekhnurjati.ac.id/jurnal/index.php/jeill/

paragraphs and achievement motivation, together with the skills to write reports ( $\mathrm{R}$ y.12 $=0.87$ at $\alpha=0.05$ significant level with $\mathrm{N}=60$ where $\mathrm{rt}=0.254$ ). From the above results can be stated that individually or jointly develop the ability and achievement motivation paragraphs made a significant contribution to the skills to write reports. This indicates that these two variables can be a good predictor for the skills to write reports.

Kata kunci: kemampuan, menulis, laporan, motivasi, prestasi

\section{A. Pendahuluan}

Kompetensi dasar dalam Kurikulum Tingkat Satuan Pendidikan (KTSP) untuk mata pelajaran bahasa dan sastra Indonesia di SMK adalah agar siswa (1) memiliki kompetensi berbahasa dan (2) memiliki kompetensi bersastra (Depdiknas, 2006: 3). Pembelajaran bahasa dan sastra Indonesia dititikberatkan kepada aspek kemampuan berbahasa, agar siswa mampu menggunakan bahasa Indonesia dengan baik dan benar, baik secara reseptif, maupun secara produktif, di samping harus pula memiliki apresiasi terhadap karya sastra Indonesia.

Menulis keterampilan berbahasa paling akhir dikuasai pelajar. Dibanding tiga kemampuan berbahasa yang lain, menulis lebih sulit dikuasai. Menurut Agus Suriamiharja, Akhlan Husen, dan Nunuy Nurjanah (1997: 25) untuk menyusun tulisan yang baik, diperlukan: pengetahuan tentang kalimat efektif dan paragraf. Kemampuan menyusun paragraf salah satu unsur yang menentukan kualitas kemampuan menulis seseorang, termasuk dalam menulis laporan. Aspek lain yang berhubungan dengan keterampilan menulis laporan adalah motivasi berprestasi yang kuat pada diri penulis. Seorang penulis yang memiliki semangat, dorongan untuk berhasil dalam segala sesuatu termasuk dalam menulis laporan. Perkiraan-perkiraan jawaban di atas, secara empiris belum teruji kebenarannya. Oleh karena itu, penelitian ini untuk menguji ada tidaknya hubungan antara kemampuan menyusun paragraf dan motivasi berprestasi dengan keterampilan menulis laporan.

Bardasarkan latar belakang masalah yang telah diuraikan di atas, maka rumusan masalah dalam penelitian ini adalah sebagai berikut (1) apakah ada hubungan antara kemampuan menyusun paragraf dan keterampilan menulis laporan 


\section{Journal Indonesian Language Education and Literature Vol.1, No. 2, 2016}

http://www.syekhnurjati.ac.id/jurnal/index.php/jeill/

siswa SMK Negeri 1 Sukoharjo? (2) Apakah ada hubungan antara motivasi berprestasi dan keterampilan menulis laporan siswa SMK Negeri 1 Sukoharjo? (3) Apakah ada hubungan antara kemampuan menyusun paragraf dan motivasi berprestasi secara bersama-sama dengan keterampilan menulis laporan siswa SMK Negeri 1 Sukoharjo?

Dijelaskan oleh Winkel (1991: 73), yang dimaksud keterampilan intelektual ialah keterampilan untuk berhubungan dengan lingkungan hidup dan dirinya sendiri dalam bentuk suatu representasi, khususnya konsep dan berbagai lambang/simbol (huruf, angka, kata, gambar). Menurut Muhibbin Syah (2000: 119) keterampilan bukan hanya meliputi gerakan motorik melainkan juga pengejawantahan fungsi mental yang bersifat kognitif. Keterampilan menulis laporan adalah kesanggupan siswa dalam melaporkan segala sesuatu yang diamati ketika mereka berkunjung atau mengamati sesuatu dengan bahasa Indonesia tulis yang runtut, jelas, baik dan benar yang terukur melalui (1) isi gagasan; (2) organisasi isi laporan; (3) tata bahasa dan pola kalimat; (4) pilihan kata atau diksi; dan (5) ketepatan penggunaan ejaan.

Kemampuan merupakan kecakapan atau kesanggupan untuk menunjukkan suatu tindakan atau aktivitas. Bila dikaitkan dengan kemampuan mengembangkan paragraf berarti tindakan atau kecakapan/kesanggupan seseorang dalam mengembangkan paragraf, yang dalam hal ini adalah mengungkapkan ide, gagasan, pengalaman atau pesan komunikasi secara tertulis dalam bentuk paragraf. Paragraf adalah gagasan terkecil dari organisasi karangan yang terdiri dari kalimat utama (topik) dan kalimat penjelas yang tersusun secara logis-sistematis untuk menuangkan buah pikiran. Paragraf merupakan suatu bentuk pengungkapan gagasan berupa gubahan yang tercermin dalam rangkaian beberapa kalimat secara sistematis dan mencerminkan satu gagasan yang padu.

Kemampuan menyusun paragraf adalah kesanggupan siswa dalam menyusun rangkaian kalimat yang memenuhi syarat kelengkapan, kesatuan, keteraturan, dan kepaduan. Kemampuan tersebut terukur dengan indikator (1) kesesuaian ide dengan isi yang disampaikan (kesatuan gagasan), (2) organisasi isi, meliputi: komposisi tulisan pada paragraf (koherensi dan kohesifan antarkalimat), keruntutan, (3) 


\section{Journal Indonesian Language Education and Literature Vol.1, No. 2, 2016}

http://www.syekhnurjati.ac.id/jurnal/index.php/jeill/

ketepatan penggunaan tata bahasa dan pola kalimat (struktur kalimat), (4) ketepatan penggunaan kata /istilah (diksi), dan (5) ketepatan penggunaan ejaan dan tanda baca.

Motivasi dapat dipandang sebagai daya pendorong yang menyebabkan seseorang berbuat sesuatu untuk mencapai tujuan. Hal ini dipertegas oleh W. Huitt yang menyebutkan bahwa motivasi terlibat dalam pembentukan respon. Ini berarti bahwa perilaku tidak akan ada bila tidak ada dorongan dari dalam. Motivasi berprestasi merupakan dorongan dan keinginan yang kuat dalam diri seseorang untuk meraih prestasi yang ditandai dengan kerja keras dan perjuangan yang tidak mengenal lelah dalam bekerja maupun belajar. Motivasi berprestasi merupakan dorongan dan keinginan yang kuat dalam diri seseorang untuk meraih prestasi yang ditandai dengan kerja keras dan perjuangan yang tidak mengenal lelah dalam bekerja maupun belajar. Idikatornya: (1) durasi kegitan melalui berapa lama kemampuan penggunaan waktu untuk melaksanakan kegiatan belajar, (2) frekuensi tercermin melalui berapa sering kegiatan belajar dilakukan dalam periode tertentu, (3) ketabahan dan kemampuan menghadapi rintangan, keuletan dan kemampuan menghadapi rintangan, (4) persistensi melalui ketetapan dan kelekatan, (5) devosi tercermin melalui pengabdian pengorbanan (uang, tenaga, pikiran), (6) tingkat apresiasi melalui maksud, rencana, cita-cita, target, dan idola, (7) tingkat kualifikasi melalui berapa banyak memadainya kegiatan belajar, dan (8) arah sikap terhadap sasran.

\section{B. Metode Penelitian}

Penelitian ini dilaksanakan di SMK Negeri 1 Sukoharjo pada siswa kelas XI tahun pelajaran 2009/2010, selama enam (6) bulan, dari Januari sampai dengan Juni 2010. Metode penelitian yang digunakan dalam penelitian ini adalah metode survai melalui studi korelasional, sebab melalui jenis penelitian korelasional ini dapat dipakai untuk mendeteksi sejauh mana variasi-variasi pada suatu faktor berkaitan dengan variasi-variasi pada satu atau lebih faktor lain berdasarkan pada koefisien korelasi (Suryabrata, 1993: 26).

Desain penelitian yang menggambarkan hubungan antarvariabel ini dapat dilukiskan pada gambar berikut: 


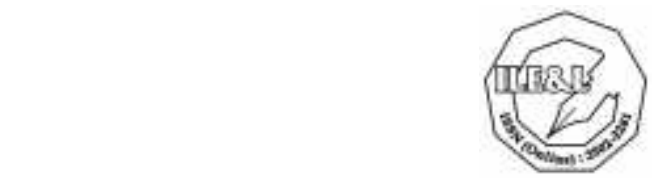

Journal Indonesian Language Education and Literature Vol.1, No. 2, 2016 http://www.syekhnurjati.ac.id/jurnal/index.php/jeill/

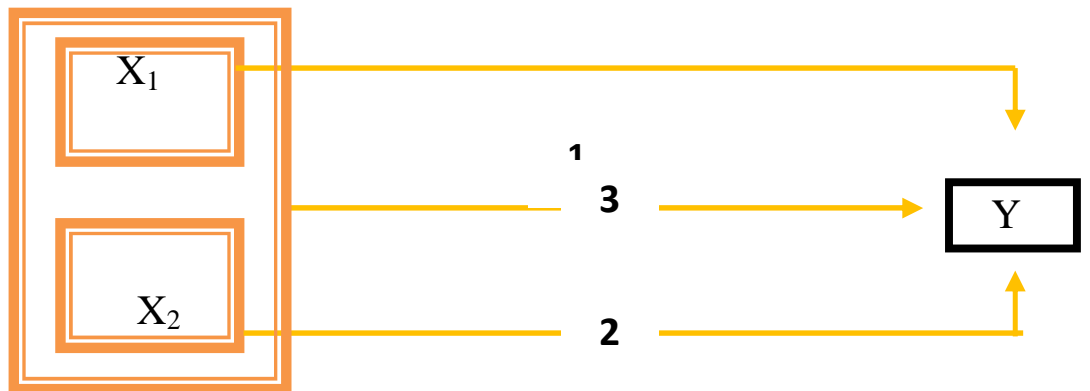

\section{Gambar 1. Desain Penelitian Korelasional}

Populasi penelitian ini ialah seluruh siswa kelas XI SMK Negeri 1 Sukoharjo yang terdiri dari lima kelas dengan jumlah total siswa ada 183 siswa. Besar sampel penelitian ini ditetapkan 60 yang diambil dengan teknik simple random sampling . Pengumpulan data tentang keterampilan menulis laporan dan kemampuan menyusun paragraf digunakan dengan teknik tes. Tes yang digunakan berbentuk tes esai dengan memberi tugas mengarang/menyusun paragraf kepada siswa. Data motivasi berprestasi dikumpulkan dengan teknik nontes yang berupa pemberian angket motivasi berprestasi pada responden (sampel ) penelitian.

Dijelaskan oleh Djaali (2001: 23) bahwa instrumen penelitian yang berskor kontinum (berkisar antara 1-5) seperti angket motivasi berprestasi digunakan rumus Korelasi Product Moment, yaitu dengan mengkorelasikan skor item dengan skor total. Penghitungan reliabilitas instrumen non-tes yang mempunyai skor berkisar 1 5 (kontinum) dipakai rumus reliabilitas Alpha Cronbach sbb

Validitas tes keterampilan menulis laporan dan kemampuan menyusun paragraf tidak diuji secara statistik tetapi hanya dilihat melalui validitas konstruk, yaitu dengan melihat aspek-aspek yang dinilai dalam menulis laporan/menyusun paragraf mengukur tingkat reliabilitas butir tes keterampilan menulis laporan/menyusun paragraf digunakan rumus statistik reliabilitas ratings.

Validitas butir angket motivasi dari 40 butir pernyataan yang diujicobakan, yang dinyatakan valid ada 36 butir, sedangkan yang dinyatakan drop atau tidak valid ada empat butir, yaitu butir pernyataan nomor 2, 18, 28, dan 33 karena koefisien 


\section{Journal Indonesian Language Education and Literature Vol.1, No. 2, 2016}

http://www.syekhnurjati.ac.id/jurnal/index.php/jeill/

validitas untuk butir tersebut hasilnya lebih kecil dari r-kritis, yakni 0,36 (pada $n=30$ taraf nyata 0,05$)$ atau $r_{h}<r_{t}$.

Hasil uji reliabilitas tes keterampilan menulis laporan yang dihitung dengan teknik reliabiltas ratings diperoleh koefisien reliabilitas sebesar 0,97. Dengan rumus dan teknik yang sama, hasil uji reliabilitas tes kemampuan menyusun paragraf diperoleh 0,98. Sementara itu, uji reliabilitas angket motivasi berprestasi yang dihitung dengan rumus Alpha Cronbach dihasilkan nilai koefisien reliabilitas sebesar 0,93. Hal ini berarti angket motivasi berprestasi juga dinyatakan reliabel.

Uji Persyaratan analisis dengan uji normalitas dengan menggunakan teknik statistik Lilliefors. Prinsip dan prosedur atau langkah-langkah pengujiannya mengacu Buku Statistik karya Sujana (1992: 466-468). Teknik analisis yang digunakan adalah teknik statistik regresi (sederhana dan ganda) dan korelasi (sederhana dan ganda). Adapun langkah-langkahnya dapat dibaca pada Sudjana (1992 : 5-131).

Menguji keberartian persamaan regresi dengan pengujian hipotesis nol $\left(\mathrm{H}_{\mathrm{o}}\right)$ menyatakan koefisien arah regresi tidak berarti (sama dengan nol), melawan hipotesis tandingan $\left(\mathrm{H}_{1}\right)$ koefisien arah regresi berarti (tidak sama dengan nol). Pengujian kelinearan regresi diperiksa lewat pengujian hipotesis nol $\left(\mathrm{H}_{\mathrm{o}}\right)$ yang menyatakan persamaan regresi linear, melawan hipotesis tandingan $\left(\mathrm{H}_{1}\right)$ persamaan regresi tidak linear. Kedua hipotesis nol untuk pengujian keberartian dan kelinearan regresi, diuji dengan teknik statistik $U j i-F$ dengan menggunakan pendekatan tabel analisis varians (ANAVA). Uji keberartian melalui pengujian hipotesis nol $\left(\mathrm{H}_{\mathrm{o}}\right)$ yang menyatakan bahwa koefisien korelasi tidak berarti (sama dengan nol), melawan hipotesis tandingan $\left(\mathrm{H}_{1}\right)$ bahwa koefisien korelasi berarti (tidak sama dengan nol) dengan menggunakan teknik statistik $U j i-t$ dengan rumus sebagai berikut: $t=\frac{r \sqrt{n-2}}{\sqrt{1-r^{2}}}$

Kriteria pengujian keberartian koefisien korelasi sederhana dinyatakan bahwa hipotesis nol ditolak jika $t_{\text {hitung }}>t_{\text {tabel }}$; dalam hal lain, hipotesis nol diterima. Selanjutnya untuk menguji signifikansi persamaan regresi ganda yang diperoleh dilakukan melalui teknik statistik $U j i-F$ dengan pendekatan ANAVA. Kriteria 
pengujian dilakukan dengan jalan membandingkan harga statistik $F$ yang diperoleh $\left(F_{\text {hitung }}\right)$ dengan $F_{\text {tabel }}$, dengan ketentuan jika $F_{\text {hitung }}>F_{\text {tabel }}$, maka persamaan regresi ganda yang diperoleh dinyatakan signifikan. Dalam hal lain, dianggap tidak signifikan.

\section{Hasil dan Pembahasan}

\section{Data Keterampilan Menulis Laporan (Y)}

Data keterampilan menulis laporan merupakan nilai yang diperoleh melalui tes keterampilan menulis laporan. Data ini memiliki nilai tertinggi 85 dan skor terendah 70. Mean (skor rata-rata) 78,07; varians 17,15; simpangan baku 4,14; modus 77, dan median 78. Harga-harga statistik deskriptif tersebut perolehannya dihitung dengan Program Excel

Tabel 1. Distribusi Frekuensi Nilai Keterampilan Menulis Laporan (Y)

\begin{tabular}{|c|c|c|}
\hline Interval & $\mathbf{f}_{\text {absolut }}$ & $\mathbf{f}_{\text {rel atif }}(\boldsymbol{\%})$ \\
\hline $68-71$ & 3 & 5,00 \\
\hline $72-75$ & 13 & 21,67 \\
\hline $76-79$ & 20 & 33,33 \\
\hline $80-83$ & 18 & 30,00 \\
\hline $84-87$ & 6 & 10,00 \\
\hline Jumlah & 60 & 100,00 \\
\hline
\end{tabular}

\section{Data Kemampuan Menyusun Paragraf $\left(X_{1}\right)$}

Data kemampuan menyusun paragraf diperoleh melalui tes kemampuan menyusun paragraf. Nilai tertinggi 87 dan terendah 69. Mean 78,13; varians 30,76; simpangan baku 5,55; modus 85; dan median 78. Harga-harga tersebut penghitungannya dilakukan dengan Program Excel. 
Journal Indonesian Language Education and Literature Vol.1, No. 2, 2016 http://www.syekhnurjati.ac.id/jurnal/index.php/jeill/

Tabel 2. Distribusi Frekuensi Nilai Kemampuan Menyusun Paragraf $\left(\mathbf{X}_{1}\right)$

\begin{tabular}{|c|c|c|}
\hline Interval & $\mathrm{f}_{\text {absolut }}$ & $\mathrm{f}_{\text {relatif }(\%)}$ \\
\hline $69-72$ & 13 & 21,67 \\
\hline $73-76$ & 11 & 18,33 \\
\hline $77-80$ & 14 & 23,33 \\
\hline $81-84$ & 12 & 20,00 \\
\hline $85-88$ & 10 & 16,67 \\
\hline Jumlah & 60 & 100,00 \\
\hline
\end{tabular}

\section{Data Motivasi Berprestasi (X2)}

Data motivasi berprestasi ini diperoleh dengan angket motivasi berprestasi. Nilai tertinggi 181 dan terendah 154. Mean 167,2; varians 44,33; simpangan baku 6,66; modus 160, dan median 167. Hasil tersebut penghitungannya dilakukan dengan Program Excel.

Tabel 3. Distribusi Frekuensi Nilai Motivasi Berprestasi $\left(\mathbf{X}_{2}\right)$

\begin{tabular}{|r|c|r|}
\hline Interval & $\mathrm{f}_{\text {absolut }}$ & $\mathrm{f}_{\text {relatif }(\%)}$ \\
\hline $154-159$ & 5 & 8,33 \\
\hline $160-165$ & 20 & 33,33 \\
\hline $166-171$ & 20 & 33,33 \\
\hline $172-177$ & 9 & 15,00 \\
\hline $178-183$ & 6 & 10,00 \\
\hline Jumlah & 60 & 100,00 \\
\hline
\end{tabular}

\section{Pengujian Persyaratan Analisis}

\section{a. Uji Normalitas Data}

Uji normalitas data dilakukan dengan menggunakan teknik Lilliefors (Sudjana, 1992: 466-467). Pengujian normalitas terhadap data keterampilan menulis laporan (Y) menghasilkan $L_{o}$ maksimum sebesar 0,0888. Dari daftar nilai kritis $L$ untuk uji Lilliefors dengan $n=60$ dan taraf nyata $\alpha=0,05$ diperoleh $L_{t}=0,1144$. Dari perbandingan di atas tampak bahwa $L_{o}$ lebih kecil daripada $L_{t}$, sehingga dapat disimpulkan bahwa data keterampilan menulis laporan (Y) berasal dari populasi yang berdistribusi normal 
Pengujian normalitas data kemampuan menyusun paragraf $\left(\mathrm{X}_{1}\right)$ menghasilkan $L_{o}$ maksimum sebesar 0, 0810. Dari daftar nilai kritis $L$ untuk uji Lilliefors dengan $n=60$ dan taraf nyata $\alpha=0,05$ diperoleh $L_{t}=0,1144$. $L_{o}$ lebih kecil daripada $L t$, Disimpulkan bahwa data kemampuan menyusun paragraf $\left(\mathrm{X}_{1}\right)$ berasal dari populasi yang berdistribusi normal. Pengujian normalitas data motivasi berprestasi $\left(\mathrm{X}_{2}\right)$ menghasilkan $L_{o}$ maksimum sebesar 0,0738. Dari daftar nilai kritis $L$ untuk uji Lilliefors dengan $\mathrm{n}=60$ dan taraf nyata $\alpha=0,05$ diperoleh $L_{t}=0,1144 . L_{o}$ lebih kecil daripada Lt. Disimpulkan bahwa data motivasi berprestasi $\left(\mathrm{X}_{2}\right)$ berasal dari populasi yang berdistribusi normal.

\section{b. Uji Signifikansi dan Linearitas Regresi}

Hasil analisis regresi sederhana $\mathrm{Y}$ atas $\mathrm{X}_{1}$ diperoleh $F_{o}$ sebesar 99,039 dan 6,96. Dari daftar distribusi $F$ pada taraf nyata $\alpha=0,05$ dengan dk pembilang $1 \mathrm{dan}$ dk penyebut 58 untuk hipotesis:

1) bahwa regresi tidak signifikan/tidak berarti diperoleh $F_{t}=4,09$; dan dengan dk pembilang 16 dan dk penyebut 42 . Hipotesis ditolak karena $F_{o}$ lebih besar daripada $F_{t}$. Dengan demikian koefisien arah regresi nyata sifatnya sehingga dari segi ini regresi yang diperoleh signifikan (berarti).

2) bahwa regresi bersifat linear diperoleh $F_{t}$ sebesar 1,89 . Hipotesis ditolak karena $F_{o}$ lebih kecil daripada $F_{t}$. Dengan demikian hipotesis yang menyatakan bahwa regresi $\mathrm{Y}$ atas $\mathrm{X}_{1}$ linear dapat diterima.

Analisis regresi sederhana $\mathrm{Y}$ atas $\mathrm{X}_{2}$ menghasilkan persamaan, masing-masing menghasilkan $F_{o}$ sebesar 103,121 dan 1,25. Dari daftar distribusi $F$ pada taraf nyata $\alpha=$ 0,05 dengan dk pembilang $1 \mathrm{dan} \mathrm{dk}$ penyebut 58 untuk hipotesis

1) Regresi tidak signifikan/tidak berarti diperoleh $F_{t}=4,09$; dan dengan dk pembilang 23 dan dk penyebut 35 . Hipotesis ditolak karena $F_{o}$ lebih besar daripada $F_{t}$. Dengan demikian koefisien arah regresi nyata sifatnya sehingga dari segi ini regresi yang diperoleh signifikan (berarti).

2) Regresi bersifat linear diperoleh $F_{t}$ sebesar 1,84. Hipotesis ditolak karena $F_{o}$ lebih kecil daripada $F_{t}$. Regresi $\mathrm{Y}$ atas $\mathrm{X}_{2}$ berbentuk linear dapat diterima. 
Journal Indonesian Language Education and Literature Vol.1, No. 2, 2016 http://www.syekhnurjati.ac.id/jurnal/index.php/jeill/

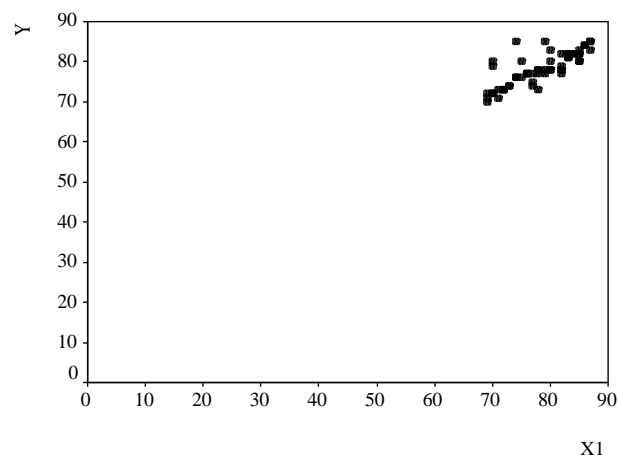

Gambar 2. Diagram Pencar Regresi Linear $Y$ atas $\mathbf{X}_{1}$

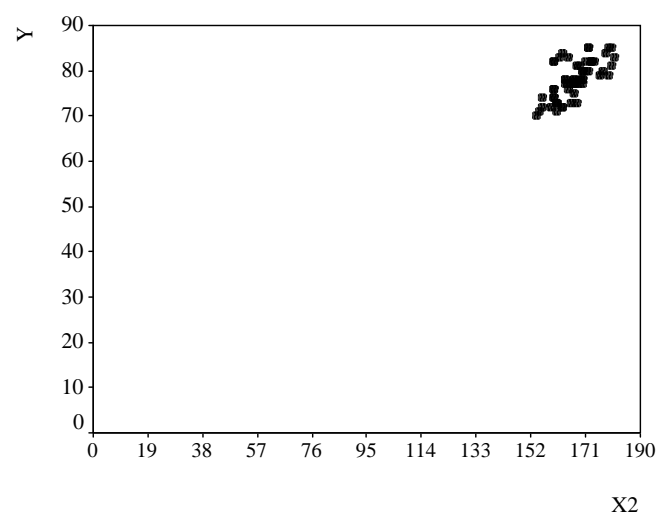

Gambar 3. Diagram Pencar Regresi Linear $Y$ atas $X_{2}$

\section{c. Pengujian Hipotesis}

\section{1) Hubungan antara Kemampuan Menyusun paragraf dan Keterampilan Menulis Laporan}

Analisis korelasi sederhana antara kemampuan menyusun paragraf dan keterampilan menulis laporan diperoleh koefisien korelasi sebesar 0,79. Untuk mengetahui signifikansi koefisien korelasi dilakukan uji t. Hasil pengujian kekuatan hubungan antara kemampuan menyusun paragraf dan keterampilan menulis laporan sebesar 10,08 yang lebih besar dari t tabel sebesar 1,67.

Hubungan positif yang signifikan antara kemampuan menyusun paragraf dan keterampilan menulis laporan. Dengan demikian hipotesis nol $\left(\mathrm{H}_{\mathrm{o}}\right)$ yang berbunyi "tidak ada hubungan antara kemampuan menyusun paragraf dan keterampilan menulis laporan” ditolak. Sebaliknya, hipotesis altenatif $\left(\mathrm{H}_{\mathrm{a}}\right)$ yang berbunyi "ada hubungan positif antara kemampuan menyusun paragraf dan 
Journal Indonesian Language Education and Literature Vol.1, No. 2, 2016 http://www.syekhnurjati.ac.id/jurnal/index.php/jeill/

keterampilan menulis laporan " diterima. Koefisien determinan kemampuan menyusun paragraf dengan keterampilan menulis laporan 0,6241 (diperoleh dari harga koefisien korelasi dikuadratkan lalu dikalikan 100)

Hal itu berarti sekitar 62,41\% variansi keterampilan menulis laporan dapat dijelaskan oleh kemampuan menyusun paragraf. Atau dengan kata lain, kemampuan menyusun paragraf memberi kontribusi (sumbangan) terhadap keterampilan menulis laporan sebesar $62,41 \%$.

\section{2) Hubungan antara Motivasi berprestasi dan Keterampilan Menulis Laporan}

Analisis korelasi sederhana antara motivasi berprestasi dan keterampilan menulis laporan diperoleh koefisien korelasi sebesar 0,68. Untuk mengetahui signifikansi koefisien korelasi dilakukan uji t. Hasil pengujian, kekuatan hubungan antara motivasi berprestasi dan keterampilan menulis laporan 7,89 yang lebih besar dari $t_{\text {tabel }}$ sebesar.

Disimpulkan ada hubungan positif yang signifikan antara motivasi berprestasi dan keterampilan menulis laporan. Dengan demikian, hipotesis nol $\left(\mathrm{H}_{\mathrm{o}}\right)$ yang menyatakan "tidak ada hubungan positif antara motivasi berprestasi dan keterampilan menulis laporan" ditolak. Sebaliknya hipotesis alternatif $\left(\mathrm{H}_{\mathrm{a}}\right)$ yang berbunyi "ada hubungan positif antara motivasi berprestasi dan keterampilan menulis laporan" diterima. Koefisien determinan motivasi berprestasi dengan keterampilan menulis laporan 0,4624 (diperoleh dari harga koefisien korelasi dikuadratkan lalu dikalikan 100).

Berarti sekitar 46,24\% variansi keterampilan menulis laporan dapat dijelaskan oleh motivasi berprestasi. Atau dengan kata lain, motivasi berprestasi memberi kontribusi (sumbangan) terhadap keterampilan menulis laporan sebesar $46,24 \%$.

3) Hubungan antara Kemampuan Menyusun Paragraf dan Motivasi Berprestasi Secara Bersama-sama dengan Keterampilan Menulis Laporan

Analisis regresi linear ganda antara kemampuan menyusun paragraf dan motivasi berprestasi secara bersama-sama dengan keterampilan menulis laporan menghasilkan arah koefisien regresi $b_{1}$ sebesar 0,$46 ; b_{2}$ sebesar 0,25 ; dan konstanta 
$b_{0}$ sebesar 0,34. Bentuk hubungan antara kemampuan menyusun paragraf dan motivasi berprestasi secara bersama-sama dengan keterampilan menulis laporan dapat digambarkan dengan persamaan garis regresi, yaitu: $\mathrm{Y}=0,34+0,46 \mathrm{X} 1+$ 0,25X2. Dilakukan uji F. Pengujian derajat signifikansi (keberartian). Hasil pengujian $\mathrm{F}_{\mathrm{o}}$ sebesar 93,91 lebih besar dari $\mathrm{F}_{\text {tabel }}$ dengan $\mathrm{dk}$ pembilang 2 dan $\mathrm{dk}$ penyebut 57 pada $\alpha=0,05$ sebesar 3, 16. Disimpulkan bahwa persamaan regresi linear antara kemampuan menyusun paragraf dan motivasi berprestasi secara bersama-sama dengan keterampilan menulis laporan adalah signifikan (berarti).

Hasil analisis korelasi ganda antara kemampuan menyusun paragraf dan motivasi berprestasi secara bersama-sama dengan keterampilan menulis laporan diperoleh korelasi (Ry.12) sebesar 0,87. Signifikansi koefisien korelasi ganda perlu dilakukan uji F. Dari hasil pengujian diperoleh $\mathrm{F}_{\mathrm{o}}$ sebesar 93,70 yang lebih besar dari $\mathrm{F}$ tabel dengan dk pembilang 2 dan $\mathrm{dk}$ penyebut 57 pada taraf nyata $\alpha=0,05$ sebesar 3,16 (lihat Lampiran 14b halaman 187).

Disimpulkan: ada hubungan positif yang signifikan antara kemampuan menyusun paragraf dan motivasi berprestasi secara bersama-sama dengan keterampilan menulis laporan.

Tabel 4. Ringkasan Hasil Koefisien Korelasi

\begin{tabular}{|c|c|c|}
\hline Hubungan & r-hitung & $\begin{array}{c}\text { r-tabel } \alpha=0,05 \\
\mathrm{~N}=60\end{array}$ \\
\hline $\mathrm{X}_{1}$ dengan $\mathrm{Y}$ & 0,79 & 0,254 \\
\hline $\mathrm{X}_{2}$ dengn $\mathrm{Y}$ & 0,68 & 0,254 \\
\hline $\mathrm{X}_{1} \mathrm{X}_{2}$ dengan $\mathrm{Y}$ & 0,87 & 0,254 \\
\hline
\end{tabular}

Hasil analisis hubungan antara kemampuan menyusun paragraf dan keterampilan menulis laporan menunjukkan adanya hubungan positif antara kedua variabel. Hasil analisis hubungan antara motivasi berprestasi dan keterampilan menulis laporan menunjukkan adanya hubungan positif antara kedua variabel. Hubungan antara kedua variabel bebas, kemampuan menyusun paragraf dan motivasi berprestasi secara bersama- 


\section{Journal Indonesian Language Education and Literature Vol.1, No. 2, 2016 \\ http://www.syekhnurjati.ac.id/jurnal/index.php/jeill/}

sama dengan keterampilan menulis laporan, memiliki hubungan yang positif dan signifikan.

\section{Keterbatasan Penelitian}

1. Hasil penelitian hanya mengungkapkan keterampilan menulis laporan siswa yang berkaitan dengan variabel kemampuan menyusun paragraf dan motivasi berprestasi dengan populasi terbatas pada siswa kelas XI SMK Negeri 1 Sukoharjo.

2. Penelitian survei sebagian data dikumpulkan menggunakan angket atau kuesioner model skala Likert, seperti instrumen penelitian yang mengukur motivasi berprestasi, instrumen penelitian semacam ini kurang mampu menjangkau aspek-aspek kualitatif dari indikator-indikator yang diukur, selain mengandung pula kelemahan.

\section{Simpulan}

Hasil analisis korelasi product-moment menunjukkan bahwa hipotesis yang menyatakan "ada hubungan positif antara kemampuan menyusun paragraf dan kemampuan menulis laporan. Ditunjukkan oleh koefisien korelasi (ry1)sebesar 0,79. Dan besarnya sumbangan variabel kemampuan menyusun paragraf (X1) terhadap variabel kemampuan menulis laporan (Y) sebesar 62,41\%.

Hasil analisis korelasi product-moment hipotesis yang menyatakan "ada hubungan positif antara motivasi berprestasi dan kemampuan menulis laporan" telah teruji kebenarannya. Kedua variabel memiliki hubungan positif. Kekuatan hubungan ditunjukkan oleh koefisien korelasinya (ry2) sebesar 0,68. Sumbangan variabel motivasi berprestasi (X2) terhadap kemampuan menulis laporan (Y) sebesar 46,24\%.

Hasil analisis korelasi ganda menunjukkan hipotesis yang menyatakan "ada hubungan positif antara kemampuan menyusun paragraf dan motivasi berprestasi secara bersama-sama dengan kemampuan menulis laporan" telah teruji kebenarannya. Kekuatan hubungan itu ditunjukkan oleh koefisien korelasi atau nilai (Ry12 )-nya sebesar 0,87. Sementara itu kedua variabel bebas tersebut secara bersama-sama memberikan sumbangan $75,69 \%$. 


\section{Journal Indonesian Language Education and Literature Vol.1, No. 2, 2016}

http://www.syekhnurjati.ac.id/jurnal/index.php/jeill/

\section{Daftar Pustaka}

Ano Karsana. 1986. Keterampilan Menulis. Buku Materi Pokok . Jakarta: Karunika Universitas Terbuka.

Angelo, Frank. D. 1980. Proces and Thought in Composition. Massachusets: Winthrop Publishers Inc.

Anwar Hasnun. 2006. Pedoman Kemampuan Menulis untuk Siswa SD, SMP, dan SMA. Yogyakarta: Andi.

Badudu J.S. 1985. Cakrawala Bahasa Indonesia. Jakarta: Gramedia.

Brown, Douglas. 1994. Teaching by Principles An Interactive Approach to Language Pedagogy. New Jersey: Prentice Hall Regent.

Byrne, Donn. 1988. Teaching Writing Skills. New Edition. Longman Group UK Limited.

Chaplin, J.P. 2000. Kamus Lengkap Psikologi, Terjemahan Kartini Kartono. Jakarta: Raja Grafindo Persada.

Crimmon, James M. Mc. 1967. Writing With a Purpose from Source to Statement. Boston: Houghton Mifflin Company.

Davidoff, L. Linda. 1987. Introduction to Psychology. New York: Mc.Graw Hill Inc.

Depdiknas. 2003. "Pembelajaran Penulisan Karya Ilmiah" dalam Materi Pelatihan Terintegrasi Bahasa Indonesia. Jakarta: Ditjen Dikdasmen.

Djago Tarigan. 1987. Membina Keterampilan Menulis Paragraf dan Pengembangannya. Bandung: Angkasa.

Elida Prayitno. 1989. Motivasi dalam Belajar. Jakarta: Depdikbud.

Eysenck, H.J, W. Arnold dan R. Meili. 1995. Encyclopedia of Psychology. West Germany: Fontana/Collins in Association with Search Press.

Farid Hadi (ed), 1991. Berbahasa Indonesia dengan Cermat. Jakarta: Pusat Pengembangan dan Pembinaan Bahasa.

Gagne, Robert M. dan Briggs, Leslie J. 1997. Principles of Instructional Design. New York : Holt, Rinehart and Winston.

Gorys Keraf. 1993. Komposisi. Ende Flores: Nusa Indah.

Harris, John. 1993. Introducing Writing. Series Editor Ronald Carter. David Nunan. England by Clays Ltd. St. Ives. Pbc.

Hedge, Tricia.1988. Resourse Books for Teachers. Series editor Alan Moley. New York: Oxford University Press.

Karti Soeharto, dkk. 1995. Teknologi Pembelajaran. Surabaya: Surabaya Intellectual Club.

Krech, Crutchfield, and Ballackey. 1962. Individual in Society. New York: Mac Graw Hill Book Company, Inc.

Lado, Robert. 1971. Language Testing: The Construction and Use of Foreign Test. New York: Mc Graw Hill Book Co.

Maslow, Abraham H. 1994. Motivasi dan Kepribadian. (Terjemahan Moekijat) Jakarta: Pustaka Binaman Pressindo.

Ngalim Purwanto. 2000. Psikologi Pendidikan. Bandung: Remaja Rosda Karya.

Pasaribu dan Simanjuntak. 1983. Proses Belajar Mengajar. Bandung: Tarsito. 


\section{Journal Indonesian Language Education and Literature Vol.1, No. 2, 2016}

http://www.syekhnurjati.ac.id/jurnal/index.php/jeill/

Sabarti Akhadiah, dkk. 2001. Menulis I. Buku Materi Pokok. Jakarta: Pusat Penerbitan Universitas Terbuka.

Sardiman, A.M. 2001. Interaksi dan Motivasi Belajar Mengajar. Jakarta: Raja Grafindo Persada.

Sumadi Suryabrata. 1998. Psikologi Kepribadian. Jakarta: Rajawali.

Suparman Natawidjaja. 1979. Bimbingan Cakap Menulis. Jakarta: Gunung Mulia.

Sternberg, Robert J. 1994 Encyclopedia of Human Intelligence. New York: Macmillan Publishing Company.

Toeti Soekamto, dkk. 1992. Prinsip Belajar dan Pembelajaran. Jakarta: Depdikbud.

Udin S. Winataputra dan Tita Rosita. 1996/1997. Belajar dan Pembelajaran. Jakarta: Depdikbud.

Warren, Howard C. 1994. Dictionary of Psychology. Cambridge, Massachusetts: Houghton Mifflin Company.

Winkel, W.S. 1991. Psikologi Pendidikan dan Evaluasi Belajar. Jakarta: Balai Pustaka.

Zaenal Arifin dan Amran Tasai.1985. Bahasa Indonesia untuk Perguruan Tinggi. Jakarta: Gunung Mulia.

http:// www. Pikiran rakyat.Com/cetak/2005/1205/23/1104. htm. Diakses 3 Desember 2009.

(http://chiron.voldosta.edu/Whuitt) diakses 4 Februari 2006. 